Georgia State University

ScholarWorks @ Georgia State University

8-1-2012

\title{
A Closer Look at Nonparticipants During and After the Great Recession
}

Julie L. Hotchkiss

Georgia State University, julie.I.hotchkiss@atl.frb.org

M. Melinda Pitts

Federal Reserve Bank of Atlanta, melinda.pitts@atl.frb.org

Fernando Rios-Avila

Federal Reserve Bank of Atlanta, fernando.rios@atl.frb.org

Follow this and additional works at: https://scholarworks.gsu.edu/uwrg_workingpapers

\section{Recommended Citation}

Hotchkiss, Julie L.; Pitts, M. Melinda; and Rios-Avila, Fernando, "A Closer Look at Nonparticipants During and After the Great Recession" (2012). UWRG Working Papers. 63.

https://scholarworks.gsu.edu/uwrg_workingpapers/63

This Article is brought to you for free and open access by the Usery Workplace Research Group at ScholarWorks @ Georgia State University. It has been accepted for inclusion in UWRG Working Papers by an authorized administrator of ScholarWorks @ Georgia State University. For more information, please contact scholarworks@gsu.edu. 
Working Paper 2012-8-1

August 2012

\section{A Closer Look at Nonparticipants During and After the Great Recession}

Julie L. Hotchkiss

Georgia State University

M. Melinda Pitts

Federal Reserve Bank of Atlanta

Fernando Rios-Avila

Federal Reserve Bank of Atlanta 


\title{
A Closer Look at Nonparticipants During and After the Great Recession
}

\author{
Julie L. Hotchkiss, M. Melinda Pitts, and Fernando Rios-Avila
}

\author{
Working Paper 2012-10 \\ August 2012
}

\begin{abstract}
This paper uses matched individual-level data from the Current Population Survey to determine that around the 2008 recession, there was a significant upward shift in trend of the share of labor force leavers giving "Schooling" and "Other" as the reason for absence from the labor market. This trend shift is observed primarily among workers between the ages of 25 and 54 and is widespread across all educational groups with at least a high school degree. In addition, the upward shift in the trend of the schooling reason share occurred among workers previously employed in occupations and industries with varying degrees of job losses during the recession. This shift suggests it was a widespread phenomenon and not isolated among sectors or occupations that suffered the most during the recession. The implication is that the upward shift in the schooling reason share has more likely been a response to lower opportunity costs of schooling during economic downturns rather than the result of workers trying to overcome skill mismatch in the labor market. In addition, since transition rates to the labor force are highest among those giving "Schooling" and "Other" as reasons for absence, the decline in labor force participation since 2008 is likely more transitory than permanent.
\end{abstract}

JEL classification: J21, J22

Key words: nonparticipation, labor force participation, labor market transition, great recession

The authors thank John C. Robertson and participants at the Federal Reserve System Applied Microeconomics Conference for helpful comments. The views expressed here are the authors' and not necessarily those of the Federal Reserve Bank of Atlanta or the Federal Reserve System. Any remaining errors are the authors' responsibility.

Please address questions regarding content to Julie L. Hotchkiss (contact author), Research Department, Federal Reserve Bank of Atlanta and Georgia State University, 1000 Peachtree Street N.E., Atlanta, GA 30309-4470, 404-498-8198, julie.l.hotchkiss@atl.frb.org; M. Melinda Pitts, Research Department, Federal Reserve Bank of Atlanta, 1000 Peachtree Street N.E., Atlanta, GA 30309-4470, 404-498-7009, melinda.pitts@atl.frb.org; or Fernando Rios-Avila, Research Department, Federal Reserve Bank of Atlanta and Georgia State University, 1000 Peachtree Street N.E., Atlanta, GA 30309-4470, 404-498-8198, fernando.rios@atl.frb.org.

Federal Reserve Bank of Atlanta working papers, including revised versions, are available on the Atlanta Fed's website at www.frbatlanta.org. Click "Publications" and then "Working Papers." Use the WebScriber service (at www.frbatlanta.org) to receive e-mail notifications about new papers. 


\section{A Closer Look at Nonparticipants During and After the Great Recession}

\section{Introduction}

Since the early 1960s, the labor force participation rate (LFPR) had progressed in a steady march upward, driven primarily by the increasing participation rates of women (see Figure 1). This trend was arrested in the late 1990s. This trend reversal occurred prior to the start of the 2001 recession, suggesting that a change in demographic and behavioral factors might be playing an important role in the reversal of the upward trend (for example, see Hotchkiss 2006).

[Figure 1 here]

Between 2005 and 2007, the LFPR stabilized, but began to decline once more with the onset of the 2008 recession at a rate exceeding that seen in the early 2000 s. The dramatic rate of decline in the LFPR is alarming to some economists because, in the absence of significant productivity increases, a decline in the LFPR could slow the economy's growth, especially if it is permanent, rather than temporal. ${ }^{1}$ Most analysts agree that there is a significant gap between actual declines in labor force nonparticipation and declines in "trend" labor force participation that might be expected as the result of an aging baby boom generation (for example, see Aaronson et al. 2012). In other words, since 2008 there have been a growing number of "unnatural" nonparticipants.

The question is whether the labor force exit of these unnatural nonparticipants is likely to be more permanent or temporal. The purpose of this paper is to address this question by exploring the reasons people give for their labor force absence. The reason for absence, or activity while absent from the labor market, could have implications for economic growth. For

\footnotetext{
${ }^{1}$ In addition, Kudlyak and Schwartzman (2012) have found that movements in nonparticipation have played a significant (and unprecedented) role in unemployment rate dynamics during the 2008 recession.
} 
example, if an increasing share of non-participants are postponing entering or leaving the labor force to attend school, this could be viewed as an investment in future growth and could work to counteract any skill mismatch that may exist in the labor market.

The implication of falling LFPRs is quite different if the increase in non-participation is the result of increases in retirement, disability, or caring for family members (other common reasons for leaving the labor market besides schooling), since transitions back into the labor market are lower among these nonparticipants and because if they do return their skills may have atrophied, reducing productivity.

\section{Data and Methodology}

The Current Population Survey (CPS) is a monthly survey administered by the Bureau of Labor Statistics in order to assess the activities of the population, estimate the number of people who are employed and unemployed, and subsequently calculate the labor force, labor force participation rate, and the unemployment rate. One feature of the CPS allows us to address the questions posed above. Each person in the CPS is interviewed for four consecutive months, not interviewed for eight, and then interviewed again for four months. Hence, we can identify those people who were in the labor force last year (either employed or unemployed) and not in the labor force this year, and why they are not in the labor force. Unfortunately, if somebody moves, they are lost from the sample, but for those who stay put in the same house, we are able to observe their activity from one year to the next. Since the analysis here depends on observing an individual in both years, each observation is weighted by a simple average of the CPS basic weight in $t$ and $t-1$ (see Shimer 2012 and Kudlyak and Schwartzman 2012).

The issue of attrition bias may be of some concern for generalizability of results if there 
is systematic selection of successful matches across individual characteristics from one year to the next (see Peracchi and Welch 1995 and Stewart 2007). Appendix A contains two tables of means for individuals who were able to be matched across one year (found in both $t-1$ and $t$ ); means for individuals who were in $t-1$, but not found in $t$; and means for the full sample in $t-1$, regardless of whether or not they are found in $t$. One table is for everyone 16 years and older, the second table is for those only aged 25-54, who are the primary sample of focus for this paper. The tables also contain a statistical test of the difference in those means. Across all characteristics available, there was only a statistical difference in the age and marital status of the matched sample compared with the unmatched sample (and also retirement status, but only among the full $16+$ sample). The implication is that the matched sample is fairly representative of the population as a whole, and even of those who are most likely to have moved -- the unmatched sample.

While it is possible to construct monthly flows with these data, for the purposes in this paper, the year-to-year flows are of greater interest. The year-to-year flows allow leavers time to settle on an alternative activity, such as schooling, and we are more interested in longer-term implications of the dynamics. ${ }^{2}$ The data used for the analysis begin in September 1996 and end in March 2012.

A person classified as out of the labor force is asked for the primary reason why he/she was neither working nor looking for a job. ${ }^{3}$ The answer can be classified into five options: (1) ill or disabled, (2) in school, (3) taking care of someone in the household, (4) retired, or (5) other.

\footnotetext{
${ }^{2}$ It is not known what took place during the year between observations, merely that the person was in the labor market one year (either employed or unemployed) and not in the labor market the next, and the reason for nonparticipation.

${ }^{3}$ While the BLS only reports the number of people in each of these categories for those classified as "marginally attached" (i.e., want a job, available to work, and have looked for a job in the previous year, but not currently looking), they ask the question of each nonparticipant and these responses are available in the individual micro data.
} 
Over time, we expect to see an increasing share of "retired" among the answers given as baby boomers continue to enter retirement age. For the same reason, we might see an increasing share of ill and disabled. An increasing share of these two categories presents an unmistakable decline in the human capital stock available to fuel economic growth (ceteris paribus). Individuals might also decide to take early retirement or seek disability benefits in the absence of job prospects during a recession, with little chance of return once the recession concludes. It would be unclear how to regard "taking care of someone in the household" or "other," since household care can be considered productive activity and, obviously, exact information on what "other" represents, as far as contributions to economic growth is concerned, is difficult to discern. ${ }^{4}$ Historical transitions rates for each nonparticipation reason will be investigated to make an assessment as to whether these exits from the labor force should be considered more permanent or temporary.

\section{A. An Initial Look at Trends in Nonparticipation Reasons}

Figure 2, Panel (a), shows the trends in levels of people 16 years and older leaving the labor force. Trend shifts upward in non-participation during or after the 2008 recession are notable in all reasons given except "Disable or Ill;" the number of people (in the matched sample) giving this reason for leaving the labor force began rising much earlier, since before 2006. In addition, the upswing in the transition into retirement at the end of the 2008 recession is consistent with other research that finds increased transitions into retirement during significant economic downturns (see Coile and Levine 2007). The apparent lag seen here may have something to do with the severity of the financial crisis that accompanied the economic downturn.

\footnotetext{
${ }^{4}$ The BLS defines the other category as individuals with transportation and/or childcare issues that prevent an individual from working as well a number of individuals with undefined reasons.
} 
However, since non-participation has been rising overall, it is more instructive to look at the distribution of the reasons given for leaving the labor force. This will provide a more accurate reflection of changes in the behavior of those exiting the labor force. Panel (b) of Figure 2 illustrates that among people leaving the labor force from one year to the next, the share doing so for retirement is actually slightly lower post 2008 recession than during the recession. The share attending school appears flat since mid-recession; the share taking care of household members has risen since the end of the recession; the share stating disability or illness took a dip post-recession, but has since risen; and the share indicating non-participation for "other" reasons has risen markedly since the recession, with a recent slight decline.

[Figure 2 here]

Figure 2 masks the significant difference in reasons given for absence by labor force leavers of different age groups. Figure 3 provides the trend shares seen in Figure 2, by age groups. The first noticeable, and not surprising, difference across the panels is the predominant reason given for absence in each age group. The majority of 16-24 year old labor force leavers are absence from the labor market because of schooling; the predominant reason of absence among 25-54 year olds is caring for someone in the household; and retirement is the primary reason for absence among those 55 years and older.

[Figure 3 about here]

With respect to changes in trends around the recession, there is not any obvious shifts in trends among those 55 years and older. Among 16-24 years olds, there was an upward trend shift in the "other" category. But it is among the 25-54 year olds where we see some more dramatic, or, at least, notable trend shifts -- the share of labor force leavers giving "other" and "schooling" as reasons for absence both shifted upward during or after the 2008 recession. What 
is most notable is that these shares have risen above their relatively flat historical levels during this time period. The increased share of nonparticipants giving these reasons appears to have come from the declines in household care and disability.

Since 25-54 year olds make up the greatest share of the labor force (65\% in May 2012), and since it is among this age group where we see the apparently most dramatic trend shifts in nonparticipation reasons, the rest of the analysis will focus exclusively on this age group. Analysis of nonparticipation behavior among older and younger ages will be the focus of future work. ${ }^{5}$

Figure 4 illustrates the trend in reason shares among 25-54 years olds for men and women separately. Disability dominates the reasons among men in this age group, whereas household care is the dominant reason among women. Both men and women saw a dramatic increase in the schooling reason, whereas the share giving other as a reason appears to have increased more among men than among women.

[Figure 4 about here]

\section{B. Methodology for Determining Significance of Trend Shifts}

To analyze the change in reasons, on average, over time for non-participation, we employ a test statistic developed by Andrews (1993). This test allows the determination of whether there has been a statistically significant structural change on the parameters that describe the distribution of a variable before and after a point in time. In this case, it allows us to test whether there has been any change in the trends for reasons people give for leaving the labor force, particularly comparing reasons given prior to, during, and after the 2008 recession. Determining this will help us to understand whether there appears to be a significant change in workers'

\footnotetext{
${ }^{5}$ Tests of significance of trend shifts among older and younger nonparticipants indicated only a slightly significant increase in the reason share of "other" for both groups. All other reason shares did not experience a statistically significant trend shift during or after the 2008 recession.
} 
behavior that is driving the notable decline in labor force participation rates since the beginning of 2008 .

The basic idea of the Andrews (1993) test is similar to what is often referred in the literature as a Chow test (Chow 1960), which involves comparing the goodness of fit of alternative models with different assumptions on parameter stability. Assuming that the series of interest $y_{i}$ (e.g., share of reason for non-participation) follows a linear trend with parameter stability, the null hypothesis implies that $y_{i}$ can be written as:

$$
y_{i}=a_{0}+a_{1} * t+e_{t} \text { for } t=1 \ldots T T \text {. }
$$

The alternative hypothesis is the existence of a one-time structural change in time $T$, such that:

$$
\begin{aligned}
& y_{i}=a_{10}+a_{11} * t+e_{1 t} \text { for } t=1 \ldots T \\
& y_{i}=a_{20}+a_{21} * t+e_{2 t} \text { for } t=T+1 \ldots T T .
\end{aligned}
$$

In the case that $\mathrm{T}$ is known, one can form Wald, LM, or LR statistics to test the null hypothesis of no structural change. Let's define $\pi$ as $\frac{T}{T T}$. In this case, these statistics can be defined as:

$W(\pi)=T T *\left(\frac{e^{\prime} e-e_{1}^{\prime} e_{1}-e_{2}^{\prime} e_{2}}{e_{1}^{\prime} e_{1}+e_{2}^{\prime} e_{2}}\right) ; L M(\pi)=T T *\left(\frac{e^{\prime} e-e_{1}^{\prime} e_{1}-e_{2}^{\prime} e_{2}}{e^{\prime} e}\right) ; L R(\pi)=T T * \log \left(\frac{e^{\prime} e}{e_{1}^{\prime} e_{1}+e_{2}^{\prime} e_{2}}\right)$

which constitutes a simplified version of the generalized statistic proposed by Andrews (1993), when the structural change is known to be at point $\mathrm{T}^{6}$

The null hypothesis is $a_{10}=a_{20}$ and $a_{11}=a_{21}$, or, rather, structural stability. If these statistics are larger than the critical value, the null hypothesis is rejected -- there is evidence for a significant change at that point in the trend of the series. ${ }^{7}$ As stated in Cameron and Trivedi (2005), all these statistics have the same asymptotic power to test local alternatives, although

\footnotetext{
${ }^{6}$ Andrews (1993) generalizes the approach to the case where the point of structural change $\mathrm{T}$ is unknown, but is believed to be between T0 and T1 or in standardized terms between $\pi_{0}$ and $\pi_{1}$ such that $0<\pi_{0} \leq \pi_{1}<1$. In this case the proposed statistics take the form $W_{\pi_{0}, \pi_{1}}=\sup _{\pi \epsilon\left(\pi_{0}, \pi_{1}\right)} W(\pi), L M_{\pi_{0}, \pi_{1}}=\sup _{\pi \epsilon\left(\pi_{0}, \pi_{1}\right)} L M(\pi)$ and $L R_{\pi_{0}, \pi_{1}}=\sup _{\pi \epsilon\left(\pi_{0}, \pi_{1}\right)} L R(\pi)$.

${ }^{7}$ The critical value to be used are taken from Andrews (1993) pp 840, for the particular case when $\pi 0=0.5$.
} 
their distributions differ for finite samples. For the cases of linear restrictions, as shown in Bernadt and Savin (1977), one can expect to have $\mathrm{W} \geq \mathrm{LR} \geq \mathrm{LM}$, which implies that in the case of linear restrictions the Wald test statistic is more likely to reject the null hypothesis than LR or LM statistics. Cameron and Trivedi also suggest that the Wald test is often used to test statistical significance, whereas the LR/LM tests are typically used to test model specification. It is for these reasons, and a desire to be conservative in our hypothesis testing, that we rely on the LM test statistic in drawing conclusions about structural change in the reason share trends.

Because there is a possibility of more than one break point in a series, we modify the implementation of this test to improve its power to detect the presence of multiple structural changes in the series trend. Instead of using all the information available, we restrict the construction of the test to a window of $+/$ - two years from a given point in time, $t$, designated as the break point. The null hypothesis tested here is that, at any given $t$, there is no structural change when comparing the trend up to two years before $t$ and the trend observed for two years after $t$. According to Andrews (1993), the LM critical values for this test in our specification would be 5.99 and 9.21 at $5 \%$ and $1 \%$ confidence level, respectively. ${ }^{8}$

\section{Results}

\section{A. Trends for all Reasons}

Figure 5 contains the trend shares, for 25-54 year olds, for each reason given for not being in the labor force (Panel a) along with the Andrews (1993) test statistics and LM critical values indicating whether a statistically significant change took place in the series trend at a

\footnotetext{
${ }^{8}$ Since our data only go through March 2012, a longer time window than four years (+/- 2 years) is not practical. A time window two years appears to be too short to capture significant trend shifts. However, results for all three time windows $(2,4$, and 6$)$ produce fairly consistent results. Since the data only go through March 2012, test statistics calculated between March 2012 and March 2011 make use of less than two years of data beyond $t$.
} 
given point of time, $t$ (Panel $\mathrm{b})$. The null hypothesis at any given point in time is that the trend in the series is stable over a four-year window (two years before and two years after). Whenever the statistic exceeds the critical values, the hypothesis of stability is rejected -- the trend of the series two years prior to $t$ is statistically significantly different than the trend in the series for two years following $t$. The larger the value of the test statistic at time $t$, the more confident we are of a structural change at $t$.

[Figure 5 here]

Panel (a) illustrates the direction of the trend change (upward or downward shift, or arrest of an increasing or decreasing trend), while Panel (b) indicates, through the Andrews test statistic the significance of a trend shift. This set of figures indicate that the upward trend shift in the absence reasons of Schooling and Other at the 99 percent confidence level. Since the end of the recession, there has been another significant trend shift, downward, in the Other reason.

Disability, Household Care, and Retirement all experienced significant downward shifts in trend around the recession.

\section{B. Trends for Schooling and Other by Previous Labor Force Status}

One might expect that reasons given by those who have left the labor force from employment might be different from reasons primarily given by those who left from unemployment. Unemployed workers might be leaving the labor force possibly discouraged by the economic situation (a significant reduction in market or expected wage). Employed workers might be leaving due to exceptional situations that force them out of their jobs or a significant change in personal considerations (their reservation wage). Figure 6 plots the reason share trends among 25-54 year olds for the reasons of Schooling and Other to see if there is any notable difference across previous labor force status (employment vs. unemployment) in the 
trend shifts for these reasons.

[Figure 6 about here]

The patterns of upward shifts in the Schooling and Other reason shares appear to be consistent across previous labor market status. In other words, regardless of whether nonparticipants were employed or unemployed one year ago, both groups experienced similarly dramatic upward trend shifts for these reasons. One notable difference is that the upward shift among those leaving unemployment and giving Other as a reason for nonparticipation is not statistically significant, according to the Andrews test statistic. This is likely because of the smaller number of observations introduce considerable noise on the estimation of shares, making it difficult for the statistic to capture a significant and systematic change in trend among these nonparticipants.

\section{Trends for Schooling and Other by Education Status}

One might expect that leaving the labor force for reasons of schooling might be most attractive to someone for whom additional school yields the greatest marginal benefit, such as those who have some schooling already. Figure 7 illustrates that while workers at each education level experienced a shift upward in the schooling share trend during or after the 2008 recession, only for those with Some College and a Bachelor's degree does this trend shift appear to be significant from a historical perspective. In addition, only for those with some college and bachelors degrees do the shares rise above pre-recession levels by the end of the series.

[Figure 7 here]

The upward trend shift for people with Some College and Bachelor's degrees occurred just after the end of the recession. There is some evidence that those with some college and college degrees receive greater amounts of "company-provided" training than those with high 
school degrees (Marcotte 2000). The post-recession trend shift may suggest that those with some college and bachelor's degrees waited until they discovered their pre-recession "companyprovided" skills did not match the requirements of firms hiring post-recession, and were thus motivated to return to school because of some experience of skill mismatch. The question of skill mismatch will be addressed further later in the paper.

By contrast, Figure 8 plots the share trends for the Other reason by education, illustrating that the most pronounced (and significant) upward trend shift in this reason share is found among those with a high school and less than high school education level.

[Figure 8 about here]

\section{A Rise in Schooling and the Question of Skill Mismatch}

A significant upward trend shift in the Schooling reason for labor force absence begs the question of whether this could be evidence of workers discovering that the skills they took with them into the recession are not the skills demanded by employers post-recession. In other words, could the rise in schooling be indicative of the presence of skill mismatch in the post-recession labor market? Skill mismatch is often suggested as a reason why labor market weakness lingered well beyond the official end of the recession (for example, see Estavao and Tsounta 2011). Of course the alternative explanation as to why schooling has increased so dramatically during this economic cycle is that the opportunity cost of attending school is significantly lower during an economic downturn, particularly one as severe as the 2008 recession.

The analysis in this section directly addresses the question of evidence of skill mismatch post-recession. If skill mismatch is present, we might expect it to be most acutely felt among workers in those sectors/occupations that experienced the greatest employment losses. Table 1

presents each broad sector and occupational group along with the net percentage change in total 
(16+) employment between December 2007 and June 2009. Those sectors/occupations

experiencing the greatest amount of job losses during the recession are classified as "decreasing" employment. Those with the smallest amount of employment losses (typically employment gains) are classified as "increasing" employment. ${ }^{9}$ Those occupations and industries in the middle 20 percent of the job loss distribution (between the worst and best performers) were not included in the analysis.

[Table 1 here]

Construction, Manufacturing, Information, Financial Activities, and Professional and Business Services were industries that lost employment. Sales and Related; Office; Construction; Installation, Maintenance, and Production; and Transportation were occupational categories that lost employment. If skill mismatch was a significant motivator for the increased schooling share among 25-54 year olds, then we would expect to see greater evidence of this trend shift among workers in industries and occupations hardest hit during the recession, with no particular impact on workers in sectors not as severely affected.

Acemoglu and Autor (2011) argue that certain types of "middle skill" occupations are those whose demand in the U.S. is evaporating most severely. Jaimovich and Siu (2012) claim that it is during economic downturns where the labor market will cull obsolete skills by destroying jobs that use them. This may have been the case during the most recent recession, as those occupations that were hit the hardest, were the same occupations that Acemoglu and Autor (2011) classify as middle skill. So, in this section, when we refer to occupations that were the greatest job losers, one can also think of them as middle skill jobs.

\footnotetext{
${ }^{9}$ Note in Table 1 that employment in the Management occupation is classified as "increasing," although it technically experienced a minor decline overall -- this is because relative to the other occupational categories a one percent decline during this recession is relatively mild.
} 
Figure 9, Panels (a)-(b) present the shares of people giving schooling as the reason for non-participation, along with the corresponding Andrews test statistics, for occupations and industries gaining and losing employment, separately for those leaving employment and those leaving unemployment. The dashed lines correspond to the trend shift among nonparticipants previously associated with industries or occupations that increased employment during the recession and the solid line corresponds to those industries and occupations that lost jobs during the recession.

[Figure 9 here]

In all comparisons, nonparticipants previously associated with industries or occupations that gained employment during the recession were just as likely to have experienced an upward trend shift in the share out of the labor force for schooling as were nonparticipants previously associated with industries or occupations losing employment. If skill mismatch was a dominant motivator for the increase in schooling, we should have seen more lopsided evidence of the observed upward trend shift in the schooling reason among those sectors and occupations particularly hard hit during the recession. This is not the case.

\section{Conclusions and Implications}

The accelerated decline in the labor force participation rate (LFPR) since the start of the 2008 recession has been the source of much alarm in the media and among some economists. Without an accompanying rise in productivity, declines in the labor force reduce the potential for economic growth. This is of particular concern if the decline in participation is expected to be more permanent than transitory. We can get some idea of the permanency of the increase in nonparticipation by looking at the transition rates of nonparticipants back to the labor force. 
Figure 10 plots these nonparticipant-to-participant transition rates by reason of labor force absence. Nonparticipants with the highest rates of transition to the labor force are those who were absent for Other and, not surprisingly, School. Roughly 45 percent of nonparticipants absent for Other one year are in the labor force the following year. This transition rate has actually increased since 2008 through and after the recession. The transition rate among those absent for School has fallen over time from nearly 40 percent to less than 30 percent postrecession. The accelerated dip post-recession is actually statistically significant (based on the Andrews test statistics, not shown here) and is likely reflective of people extending the length of their schooling -- again, likely merely reflecting the lower opportunity cost of remaining in school imposed by a weak labor market.

[Figure 10]

The analysis in this paper identified "Schooling" and "Other" as the reasons given for nonparticipation that have seen a particularly dramatic and significant increase since the onset of the 2008 recession, especially among those aged 25-54, who make up the bulk of the labor force. The transition rates from Figure 10 suggest that much of the increased nonparticipation is more transitory than permanent, since people absent for Other and School have the highest rates of transition into the labor force. The conclusion would be quite different if the reasons given for labor force absence showing the greatest increases since 2008 had been Retired or Disability, reasons demonstrating the lowest rates of transition to the labor force.

In addition, the activities being undertaken by these "unnatural" nonparticipants is important for long-term implications of productivity growth. While is it difficult to know how the productivity of those giving Other as their reason will be affected by their labor force 
absence, we can more clearly expect some sort of human capital quality boost to the productivity of those giving Schooling as their reason for absence.

In addition, the upward trend shift in schooling occurred most significantly among all education groups (although most significantly among those with some college or a bachelors degree), and across occupations and sectors that both lost and gained employment during the recession. The widespread nature of the phenomenon suggests that it was motivated by a cyclical decline in labor market opportunity cost, rather than by a need to re-align skills postrecession in response to a mismatch of skills in the labor market. However, the evidence here does not rule out pockets of mismatch where local skill supply is not matching local skill demand. The absence of evidence here of skill mismatch in the labor market post 2008 recession is consistent with other research that has also not found evidence of skill mismatch. For example see Jayadev and Konczal (2011), Valletta and Kuang (2010), Tasci and Zaman (2010), Appelbaum (2010), and Hobijin et al. (2011).

A natural demographic decline in the LFPR is expected as the baby-boomers continue to enter retirement. However, some are claiming that LFPR as of 2011 is below the trend levels that could be solely explained by demographic changes (for example, see Aaronson et al. 2012). The results here suggest that at least some of the activity arising out of this below-trend participation could result in longer-term gains in productivity, and, thus, economic growth. Of course, only time will tell if the identified upward shift in the trend of the schooling reason for non-participation results in the expected pay-off. 


\section{References}

Aaronson, Danial; Jonathan Davis; and Luojia Hu. "Explaining the Decline in the U.S. Labor Force Participation Rate." Chicago Fed Letter No. 296 (March 2012).

Acemoglu, Daron and David Autor. "Skills, Tasks, and Technologies: Implications for Employment and Earnings. In, Orley Ashenfelter and David Card, eds. Handbook of Labor Economics, Volume 4B, Chapter 12, pp. 1043-1171. Amstersdam: Elsevier, 2011.

Andrews, Donald W. K. "Tests for Parameter Instability and Structural Change with Unknown Change Point." Econometrica 61 (4) (July 1993): 821-56.

Appelbaum, Eileen (2010), Digging Out from the Great Recession: Prospects for Jobs and Economic Growth, Presidential address. In Labor and Employment Relations Association Series. Proceedings of the $63^{\text {rd }}$ meeting. Ed. Françoise Carré and Christian Weller. Denver, CO.

Bernadt, Ernest R. and N. Eurgene Savin. "Conflict Among Criteria for Testing Hypotheses in the Multivariate Lienar Regression Model." Econometrica 45 (1977): 1263-78.

Cameron, A. Colin and Pravin K. Trivedi. Microeconomics: Methods and Applications. Cambridge and New York: Cambridge University Press (2005).

Canon, Maria E. and Mingyu Chen. "The Mismatch Between Job Openings and Job Seekers." The Regional Economist (July 2011), Federal Reserve Bank of Atlanta $<$ www.stlouisfed.org/publications/re/articles/?id=2123> (accessed 14 February 2012).

Chow, Gregory C. "Tests of Equality Between Sets of Coefficients in Two Linear Regressions." Econometrica 28(3) (July 1960): 591-605.

Coile, Courtney C. and Phillip B. Levine. "Labor Market Shocks and Retirement: Do Government Programs Matter?" Journal of Public Economics 91 (10) (2007): 1902-19.

Estevão, Marcello and Evridiki Tsounta. "Has the Great Recession raised U.S. Structural Unemployment?" IMF Working Paper WP/11/105 (2011).

Hobijn, Bart, Gardiner, Colin, and Wiles, Theodore (2011), Recent College Graduates and the Job Market, FRBSF Economic Letter 2011-09 $<$ http://www.frbsf.org/publications/economics/letter/2011/el2011-09.pdf $>$.

Hotchkiss, Julie L. "Changes in Behavioral and Characteristic Determination of Female Labor Force Participation, 1975-2005." Federal Reserve Bank of Atlanta Economic Review 2006 Q2: 1-20.

Jaimovich, Nir and Henry E. Siu. "The Trend is the Cycle: Job Polarization and Jobless Recoveries." Mimeo, Duke University Department of Economics (31 March 2012). 
Jayadev, Arjun and Michael Konczal, Michael. "The Stagnant Labor Market: Some Aspects of the Bleak Picture. Journal of Post Keynesian Economics 33(3) (2011): 435-50.

Kudlyak, Marianna and Felipe Schwartzman. "Accounting for Unemployment in the Great Recession: Nonparticipation Matters." Federal Reserve Bank of Richmond Working Paper \#12-04 (5 June 2012).

Marcotte, Dave E. "Continuing Education, Job Training, and the Growth of Earnings Inequality." Industrial and Labor Relations Review 53(4) (July 2000): 602-23.

Peracchi, Franco and Finis Welch. "How Representative are Matched Cross-sections? Evidence from the Current Population Survey." Journal of Econometrics 68(1) (1995): 153-79.

Rosenbaum, Paul R. and Donald B. Rubin. "Construction a Control Group Using Multivariate Matched Sampling Methods that Incorporate Propensity Score." The American Statistician 39(1) (1985): 33-8.

Shimer, Robert. "Reassessing the Ins and Outs of Unemployment." The Review of Economic Dynamics 15(6) (2012): 1319-38.

Stewart, Jay. "Using March CPS Data to Analyze Labor Market Transitions." Journal of Economic and Social Measurement. 32(2) (2007): 177-97.

Tasci, Murat and Saeed Zaman. "Unemployment after the Recession: A New Natural Rate?. Economic Commentary." Federal Reserve Bank of Cleveland Working Paper 2010-11 (2010).

Valletta, Rob and Katherine Kuang. "Is Structural Unemployment on the Rise?" FRBSF Economic Letter No 34 (2010) $<$ http://www.frbsf.org/publications/economics/letter/2010/el2010-34.pdf $>$. 
Figure 1. Labor Force Participation Rate, 1948-2011.

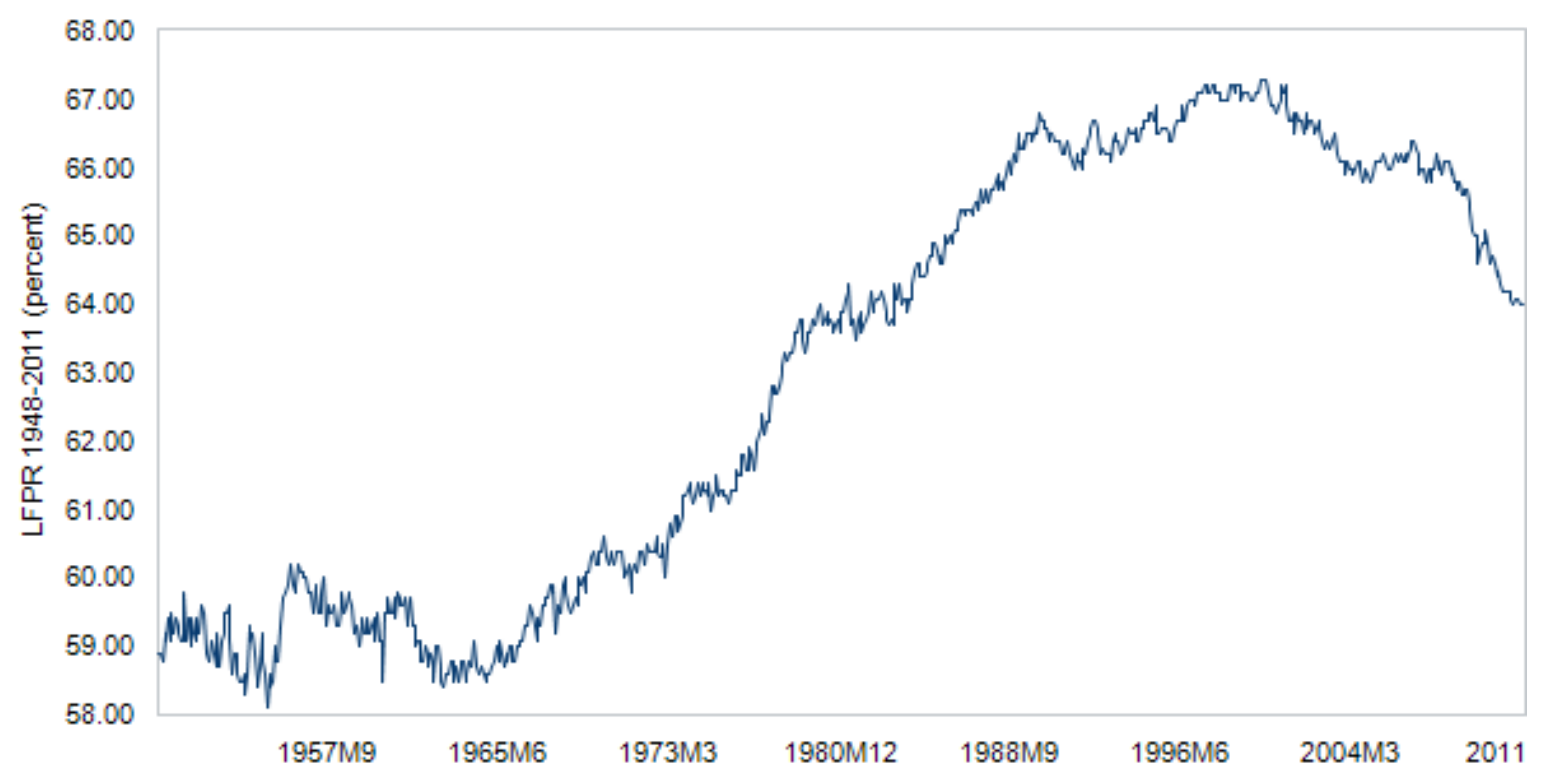

Source: Current Population Survey, Economy.com. 
Figure 2. Trends in people leaving the labor force by reason of absence, Current Population Survey, ages 16+.

Panel (a): Trends in levels.

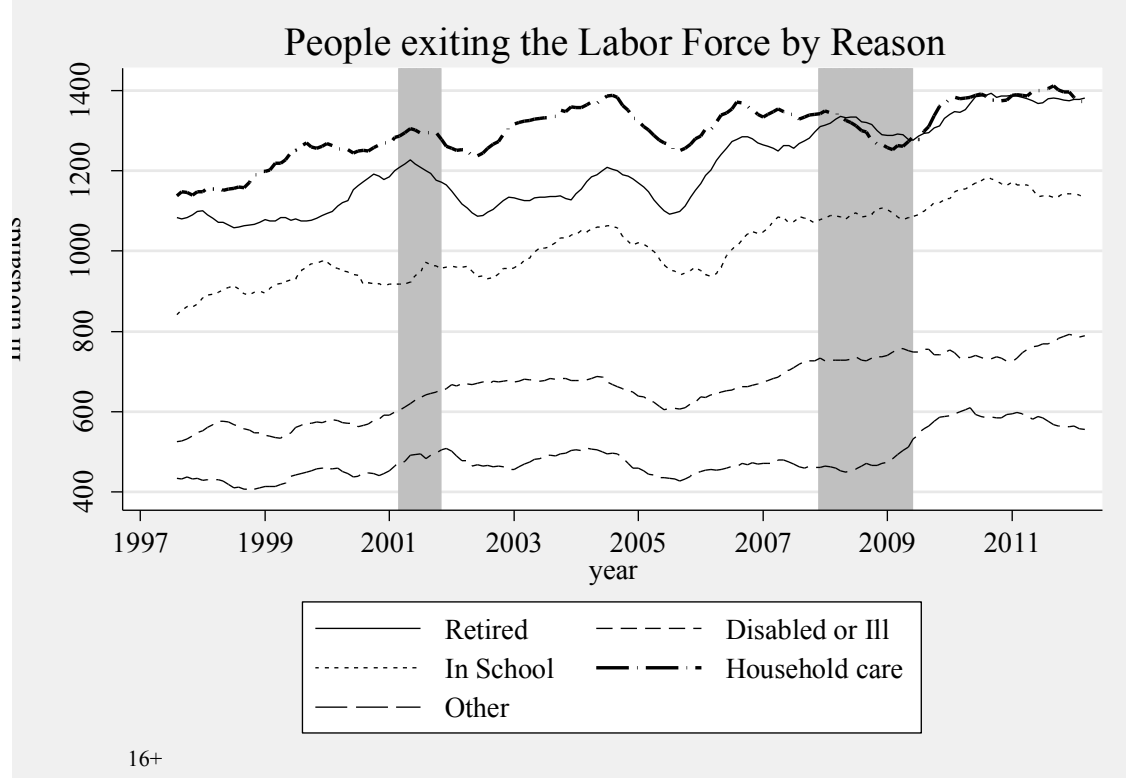

Note: 12 month moving average; levels measured in thousands.
Panel (b): Trends in shares.

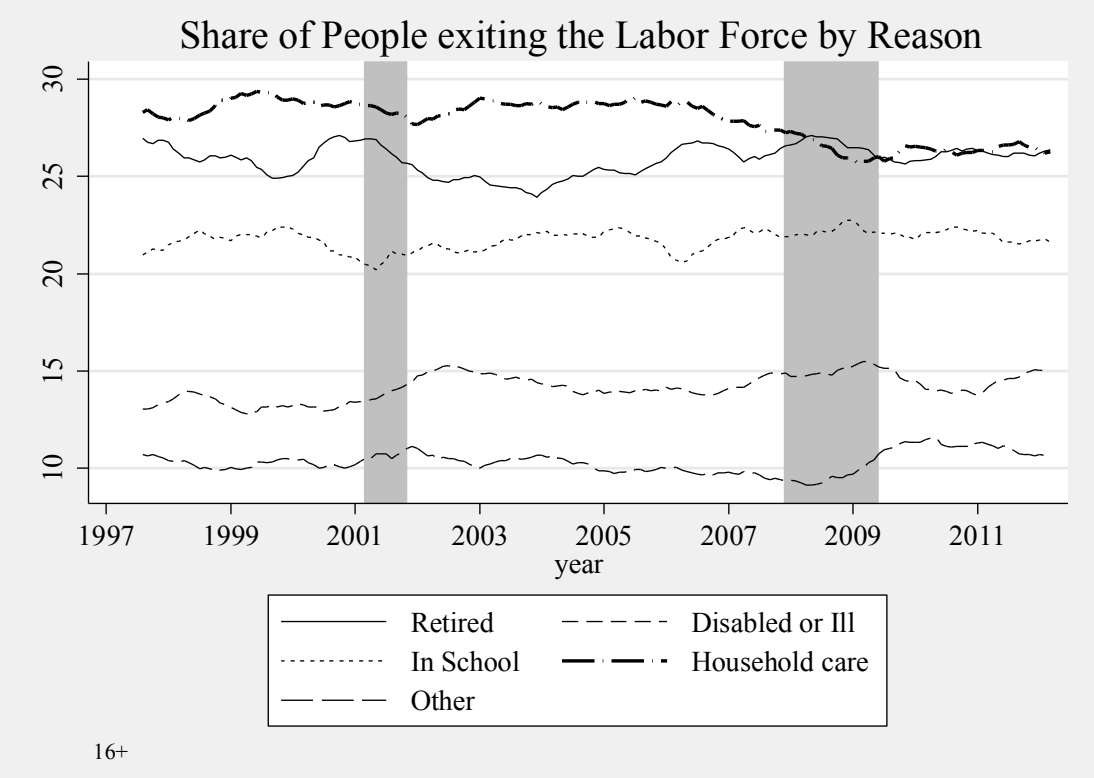


Figure 3. Trends in people leaving the labor force by reason share, Current Population Survey. by age group.

\section{Panel (a): 16-24 year olds}

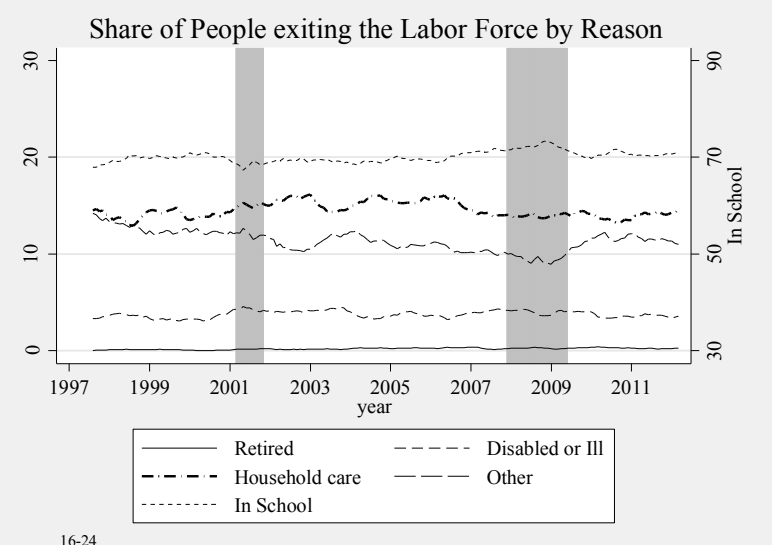

\section{Panel (b): 25-54 year olds.}

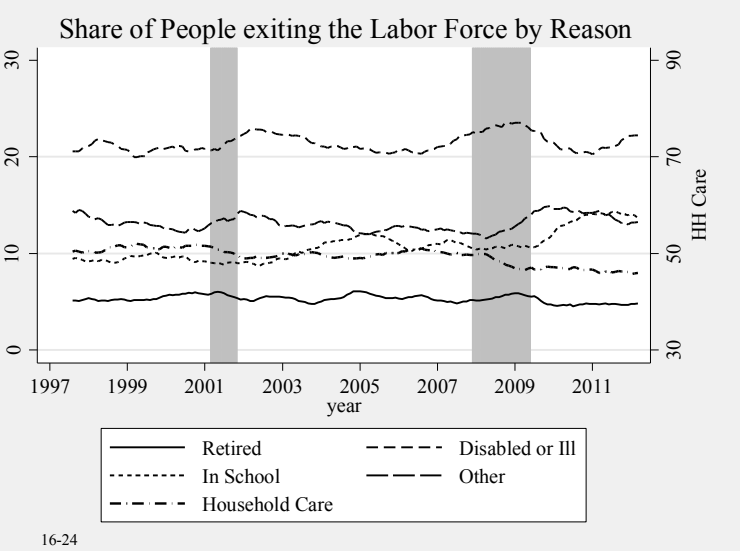

\section{Panel (c): 55 years and older.}

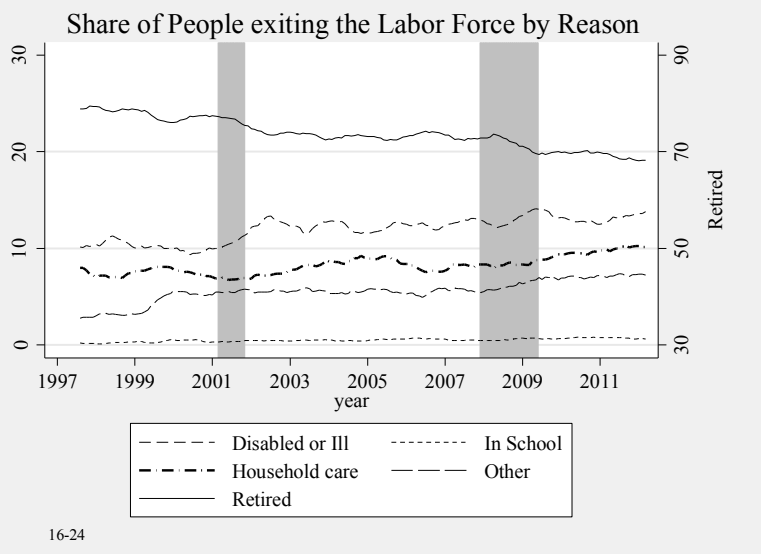

Note: 12 month moving average. 
Figure 4. Trends in people leaving the labor force by reason share, Current Population Survey, 25-54 year olds, men and women separately.

Panel (a): Men.

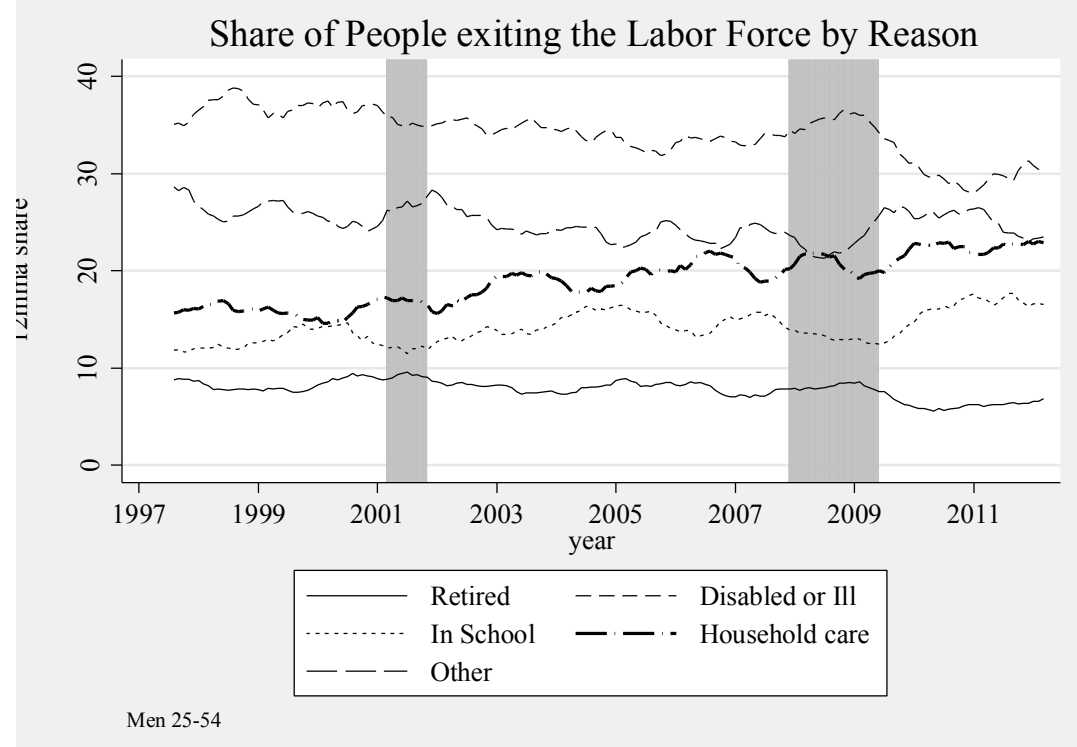

Panel (b): Women.

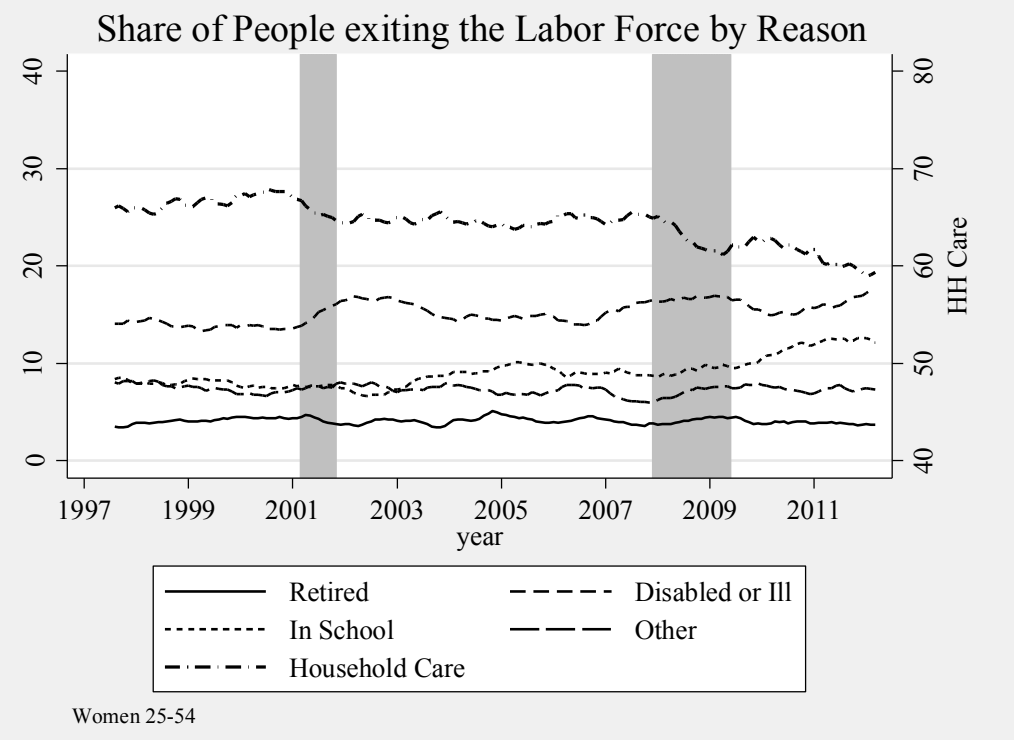

Note: 12 month moving average. 
Figure 5. Share trends by reason and Andrews (1993) test statistics and critical values for significant change in trend, each reason given for nonparticipation, ages 25-54.

\section{Panel (a): Trend shares by reason for non-participation}
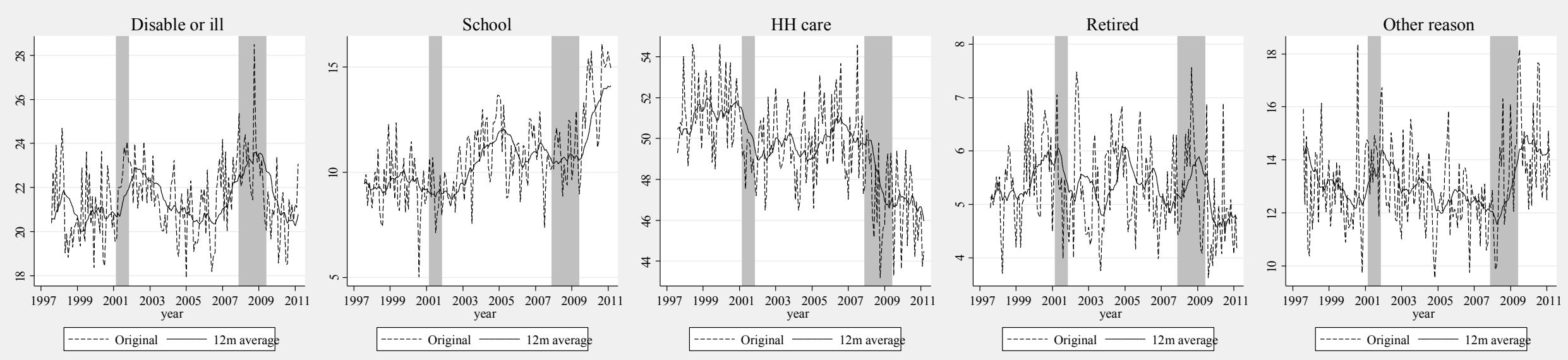

Panel (b): Andrews Test Statistics
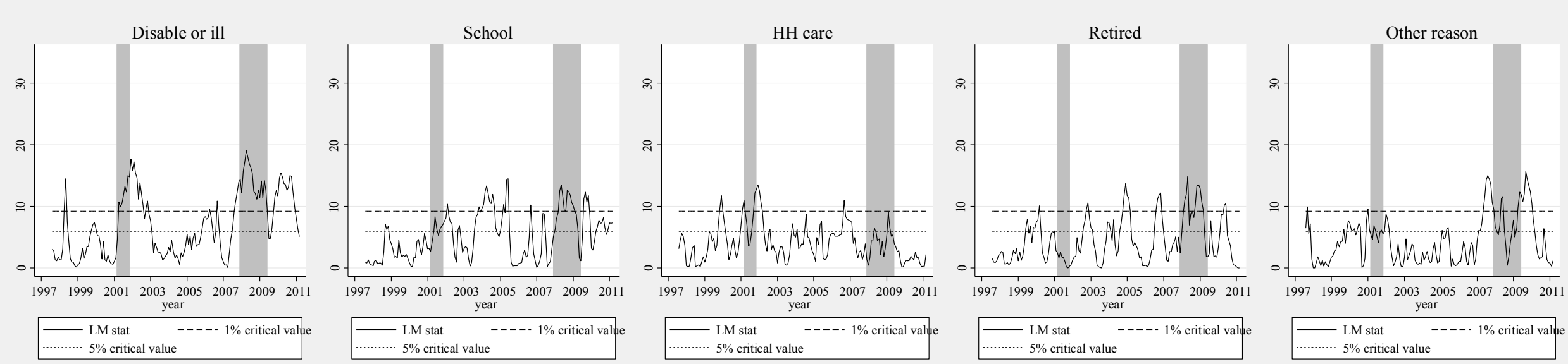

$25-54$

Notes: Data end in March 2011, so the Andrews (1993) test statistic is last calculated for March 2011, which means fewer than two full years of post $t$ data are used in the test statistic construction for each month from March 2010 through March 2011. Otherwise, the test for stability reflects a four year window, indicating whether the trend two years prior is the same as two years post each data point. 
Figure 6. Share trends for Schooling and Other nonparticipation reasons and Andrews (1993) test statistics and critical values for significant change in trend, separately by previous labor force status, ages 25-54.

\section{Panel (a): Trend shares by reason for non-participation} Leaving Employment Leaving Unemployment

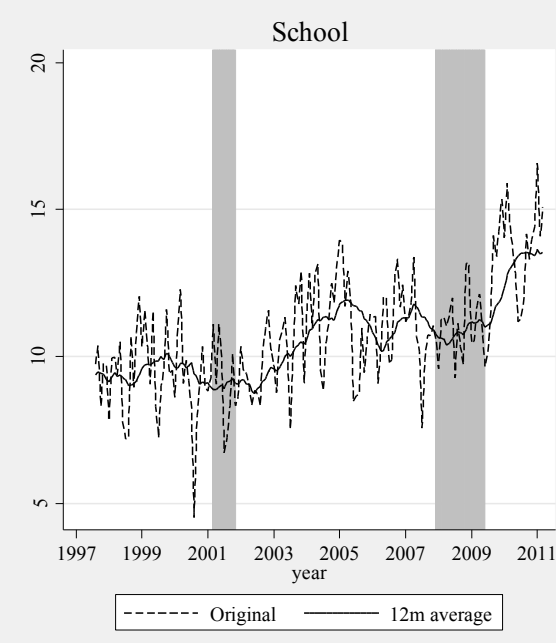

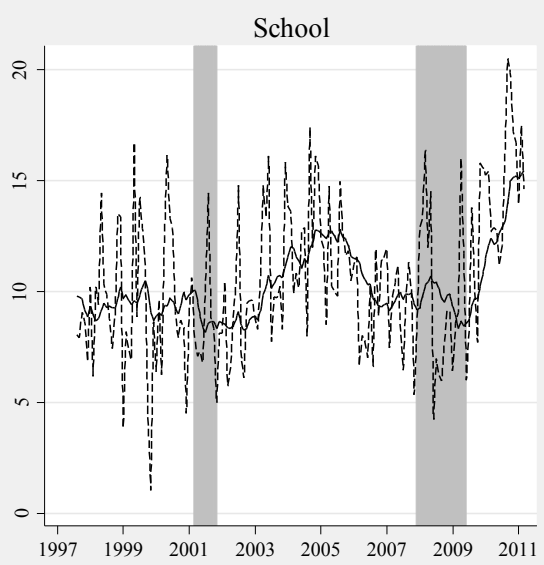

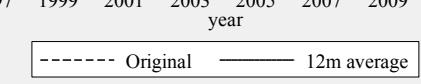

Leaving Employment

Leaving Unemployment

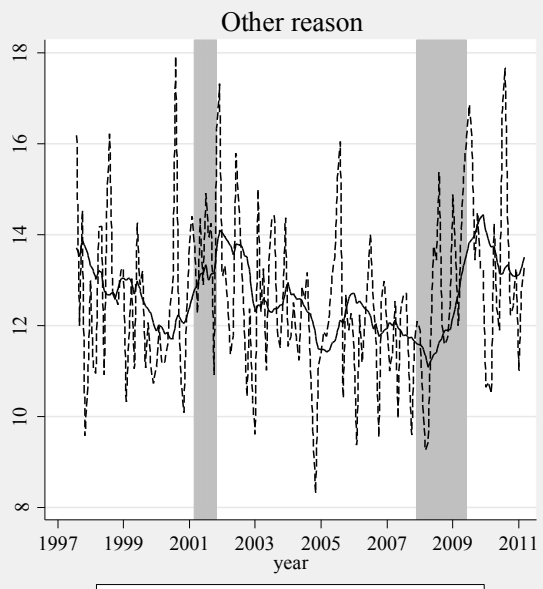

------ Original $\quad 12 \mathrm{~m}$ average

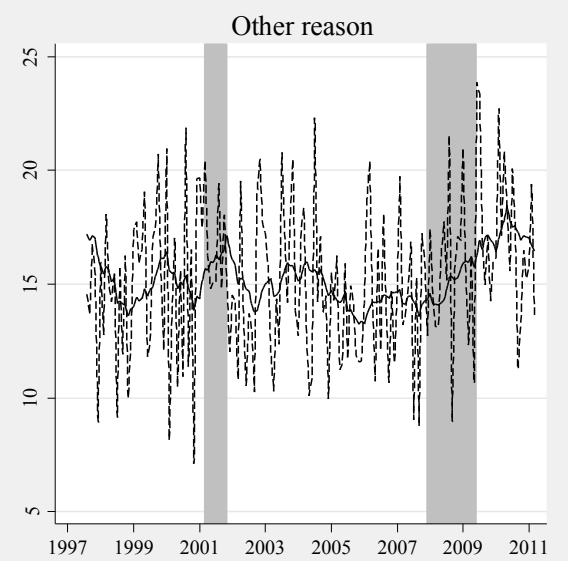

$-{ }_{------}$Original $\quad 12 \mathrm{~m}$ average

Panel (b): Andrews Test Statistics
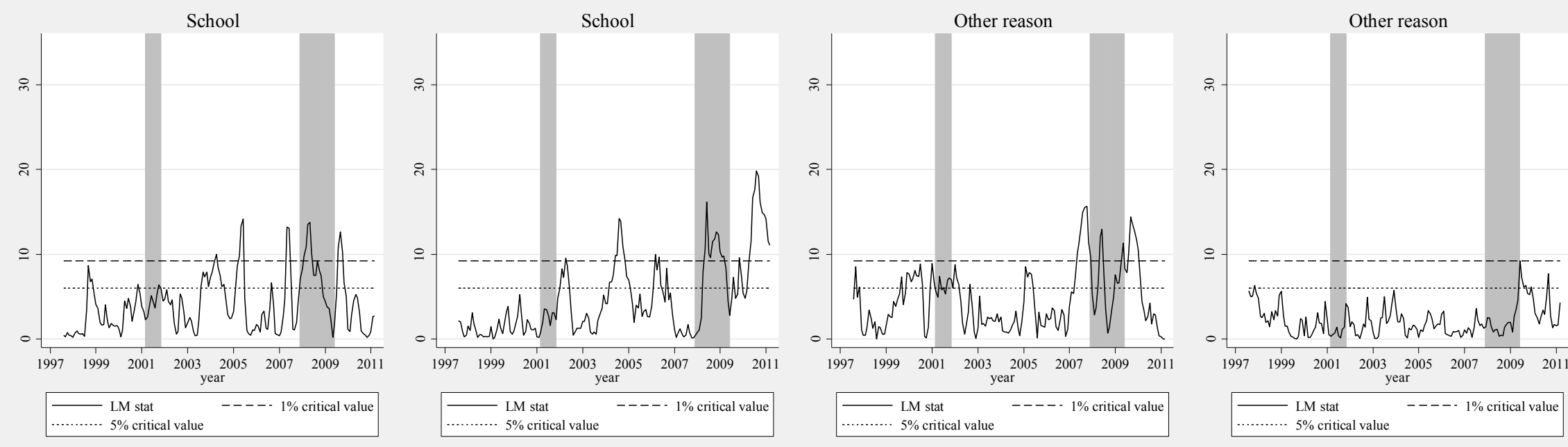
Notes: Data end in March 2011, so the Andrews (1993) test statistic is last calculated for March 2011, which means fewer than two full years of post $t$ data are used in the test statistic construction for each month from March 2010 through March 2011. Otherwise, the test for stability reflects a four year window, indicating whether the trend two years prior is the same as two years post each data point. 
Figure 7. Share trends for Schooling reason and Andrews (1993) test statistics and critical values for significant change in trend, by education, ages $25-54$.

Panel (a): Schooling trend shares by education Less than High School

High School

Some College

College Degree

Graduate
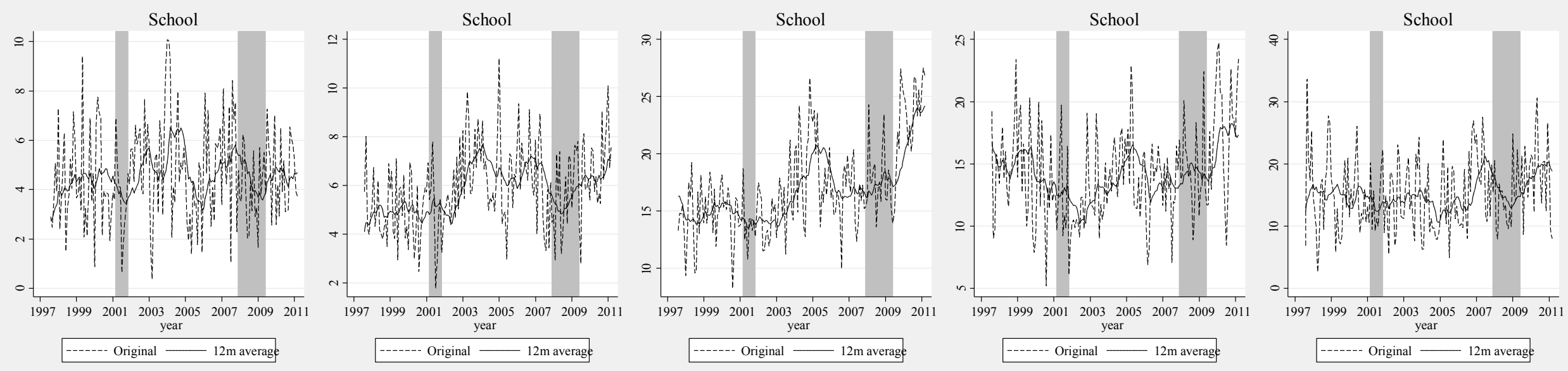

Panel (b): Andrews Test Statistics

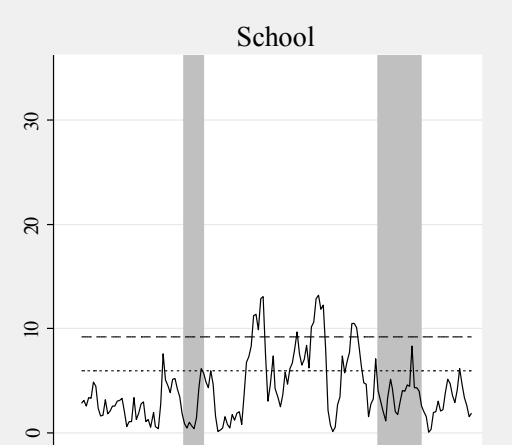

$1997 \begin{array}{lllllll}1999 & 2001 & 2003 & 2005 & 2007 & 2009 & 2011\end{array}$

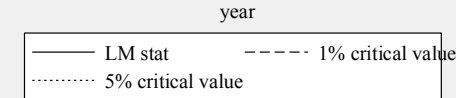

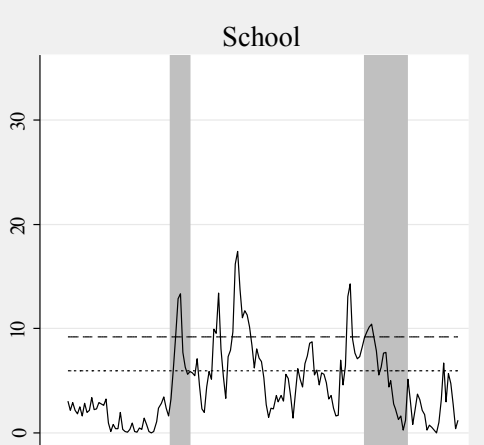

$1997 \quad 19992001 \quad 2003 \quad 2005 \quad 2007 \quad 20092011$

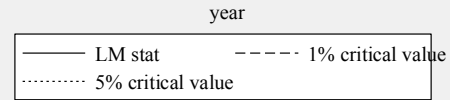

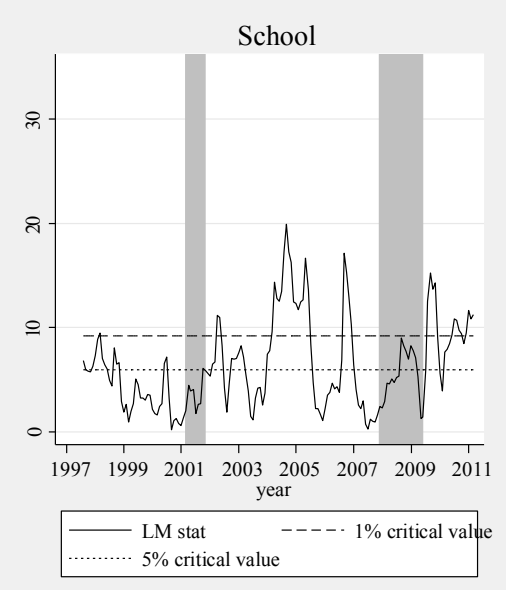
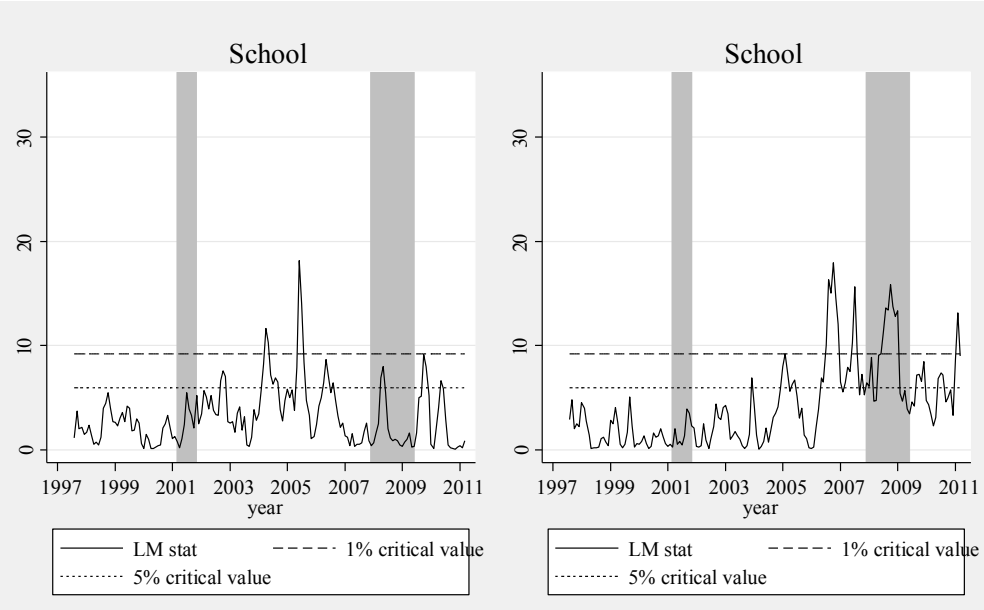

Notes: Data end in March 2011, so the Andrews (1993) test statistic is last calculated for March 2011, which means fewer than two full years of post $t$ data are used in the test statistic construction for each month from March 2010 through March 2011. Otherwise, the test for stability reflects a four year window, indicating whether the trend two years prior is the same as two years post each data point. 
Figure 8. Share trends for Other reason and Andrews (1993) test statistics and critical values for significant change in trend, by education, ages 2554.

Panel (a): Other trend shares by education Less than High School High School Some College College Degree Graduate
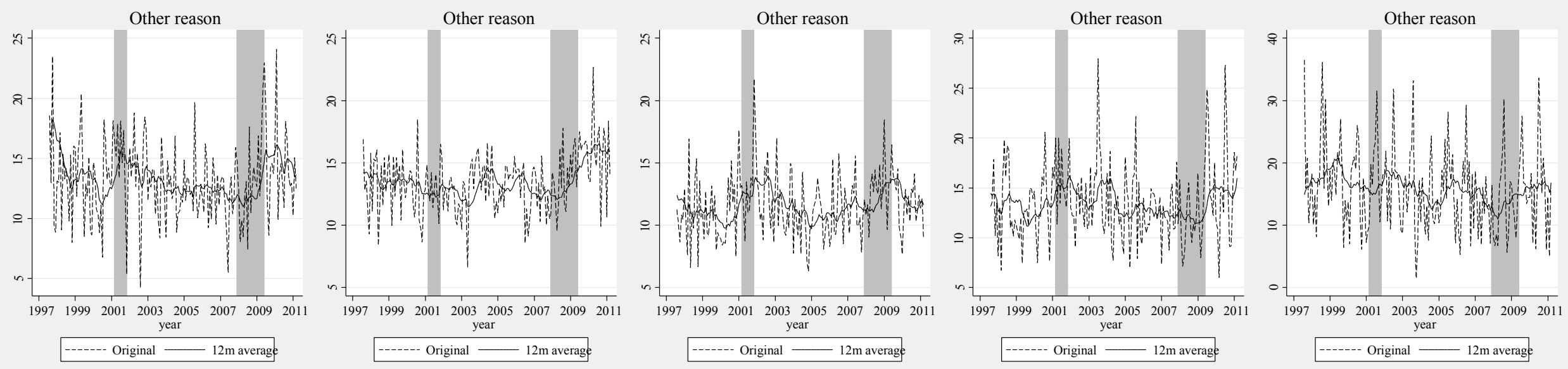

Panel (b): Andrews Test Statistics

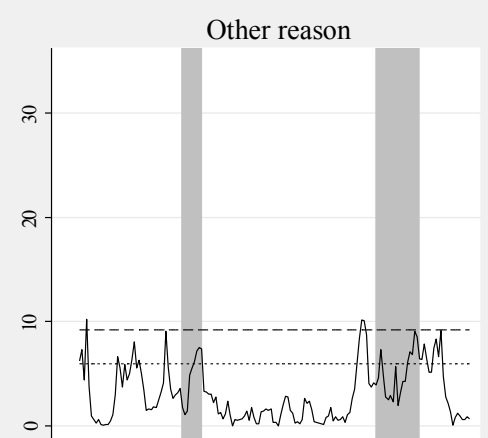

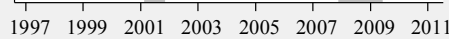

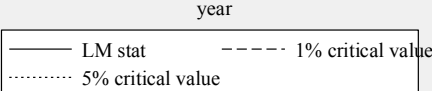

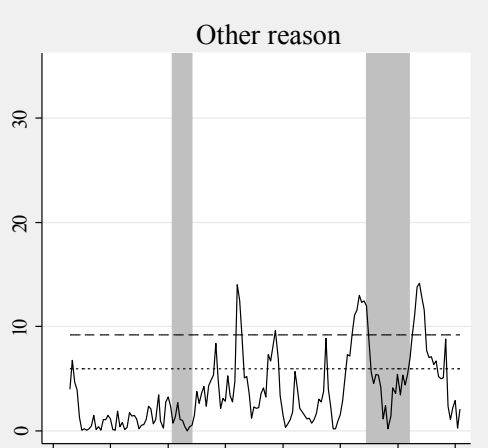

19971999200120032005200720092011

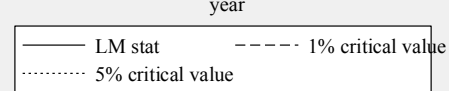

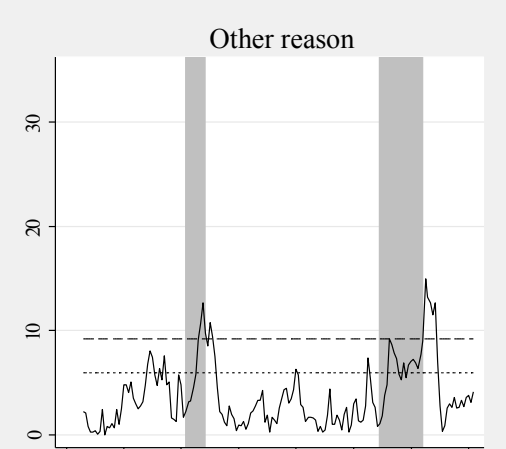

$1997199920012003 \quad 200520072009201$

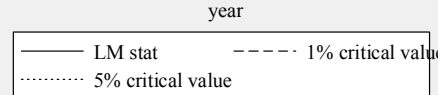

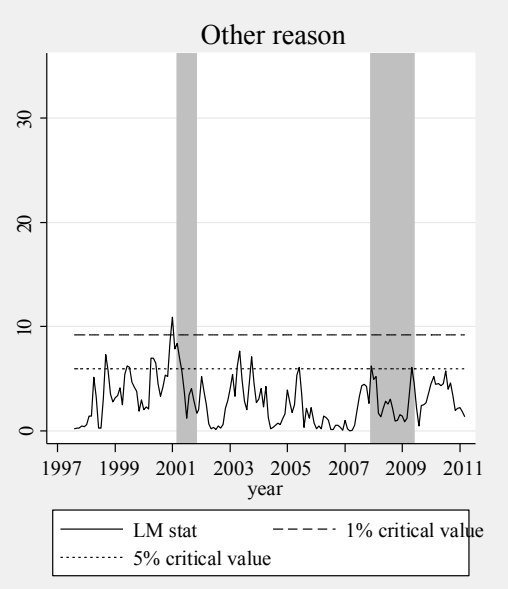

Notes: Data end in March 2011, so the Andrews (1993) test statistic is last calculated for March 2011, which means fewer than two full years of post $t$ data are used in the test statistic construction for each month from March 2010 through March 2011. Otherwise, the test for stability reflects a four year window, indicating whether the trend two years prior is the same as two years post each data point. 
Figure 9. Share trends of labor force leavers giving Schooling as the reason for being out of the labor force and Andrews (1993) statistics for significant changes in the trends, separately by industries and occupations that lost and gained jobs during the recession, ages 25-54.

Panel (a): By Industry
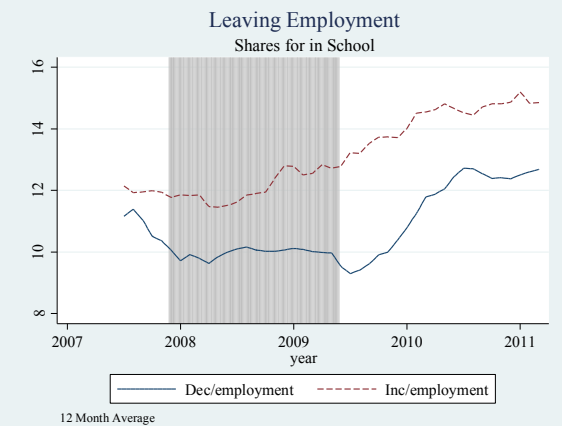

Andrew Stat

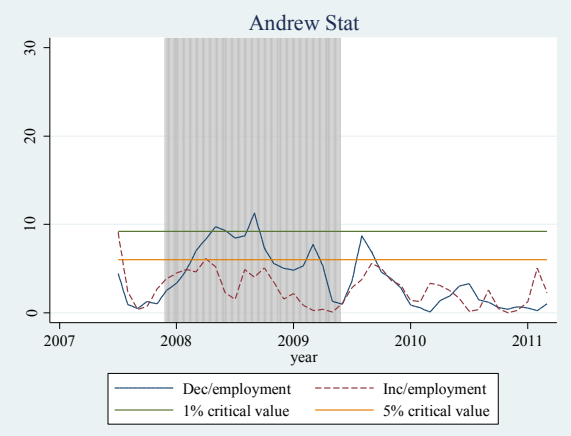

Leaving Unemployment
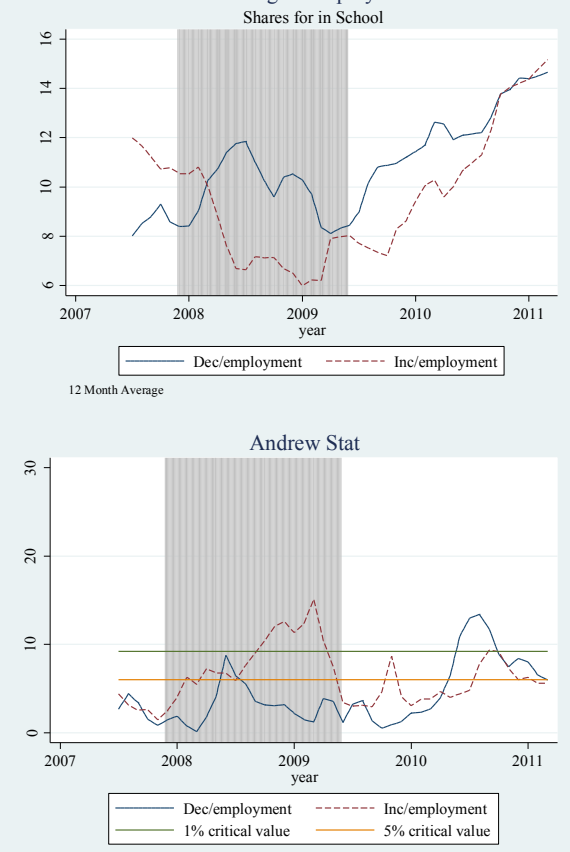

Panel (b): By Occupation
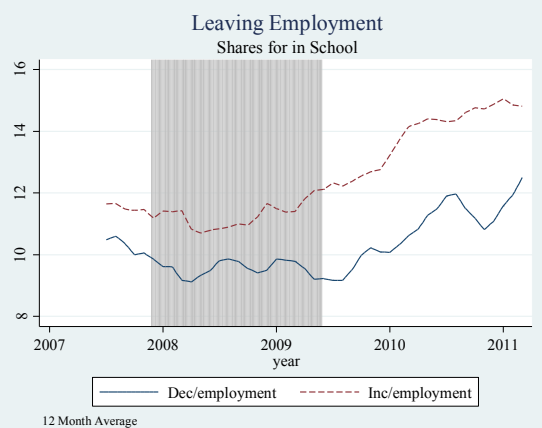

Andrew Stat

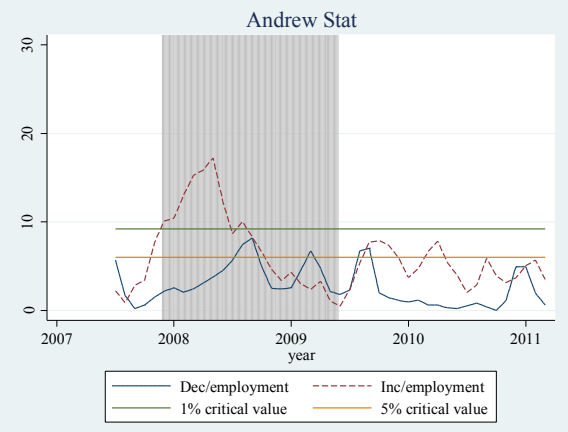

Leaving Unemployment
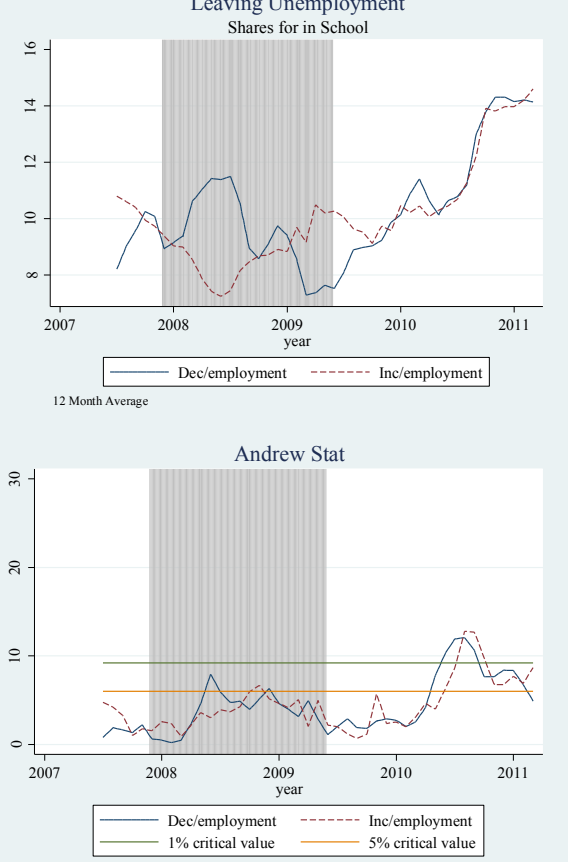

Notes: Data end in March 2011, so the Andrews (1993) test statistic is last calculated for March 2011, which means fewer than two full years of post $t$ data are used in the test statistic construction for each month from March 2010 through March 2011. Otherwise, the test for stability reflects a four year window, indicating whether the trend two years prior is the same as two years post each data point. 
Figure 10. Nonparticipant transition rates to the labor force by reason of absence, 16 years and older.

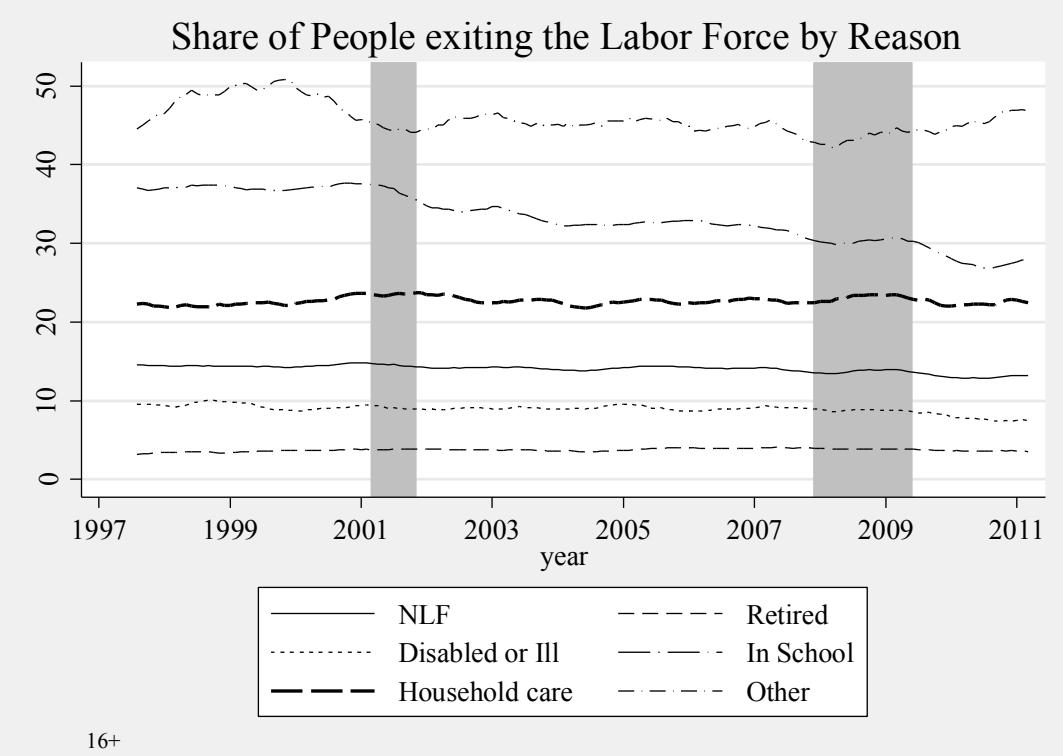

Notes: 12 month moving average. 
Table 1. Industries and occupations classified by job growth experienced between December 2007 and June 2009.

\begin{tabular}{|c|c|c|c|c|c|c|c|}
\hline Industry & $\begin{array}{c}\text { Distribution } \\
\text { of Workers } \\
(\%) \\
\end{array}$ & $\begin{array}{c}\text { Growth } \\
(\%) \\
\end{array}$ & Classification & Occupation & $\begin{array}{c}\text { Distribution } \\
\text { of Workers } \\
(\%) \\
\end{array}$ & $\begin{array}{c}\text { Growth } \\
(\%)\end{array}$ & Classification \\
\hline 1 Mining and Agriculture & $2.1 \%$ & $7.0 \%$ & Inc & 1 Management & $15.6 \%$ & $-1.0 \%$ & Inc \\
\hline 2 Construction & $7.1 \%$ & $-14.9 \%$ & Dec & 2 Professional & $21.3 \%$ & $-1.4 \%$ & -- \\
\hline 3 Manufacture & $10.3 \%$ & $-12.6 \%$ & Dec & 3 Service Occupation & $17.9 \%$ & $7.2 \%$ & Inc \\
\hline 4 Whole Sale and Retail & $14.1 \%$ & $-6.7 \%$ & -- & 4 Sales and related & $11.4 \%$ & $-5.0 \%$ & Dec \\
\hline 5 Transportation and Utilities & $5.0 \%$ & $-6.8 \%$ & Dec & $\begin{array}{l}5 \text { Office } \\
6 \text { Farming, Fishing and }\end{array}$ & $13.0 \%$ & $-8.3 \%$ & Dec \\
\hline 6 Information & $2.4 \%$ & $-11.9 \%$ & Dec & forestry & $0.7 \%$ & $12.0 \%$ & Inc \\
\hline 7 Financial Activities & $6.9 \%$ & $-8.3 \%$ & Dec & $\begin{array}{l}7 \text { Construction } \\
8 \text { Installation, Maint. and }\end{array}$ & $5.4 \%$ & $-19.3 \%$ & Dec \\
\hline 8 Professional and Business & $10.7 \%$ & $-4.7 \%$ & -- & Production & $9.0 \%$ & $-13.1 \%$ & Dec \\
\hline 9 Education and Health & $21.9 \%$ & $0.3 \%$ & Inc & 9 Transportation & $5.6 \%$ & $-9.1 \%$ & Dec \\
\hline 10 Leisure and Hospitality & $9.5 \%$ & $9.4 \%$ & Inc & & & & \\
\hline 11 Other Services & $5.0 \%$ & $4.8 \%$ & Inc & & & & \\
\hline 12 Public Administration & $4.9 \%$ & $2.8 \%$ & Inc & & & & \\
\hline Overall & & & & Overall & & & \\
\hline$\overline{\text { Decreasing }}$ & $45.9 \%$ & & & $\overline{\text { Decreasing }}$ & $44.4 \%$ & & \\
\hline None & $10.7 \%$ & & & None & $21.3 \%$ & & \\
\hline Increasing & $43.4 \%$ & & & Increasing & $34.2 \%$ & & \\
\hline
\end{tabular}

Note: Industries/Occupations in the bottom $40 \%$ of job growth are classified as decreasing, those in the top $40 \%$ are classified as increasing. 


\section{Appendix A. Sample means and statistical test of mean difference significance.}

The Standardized Difference (Sdiff) is generally used when comparing means for large samples. Regular $\mathrm{t}$ or $\mathrm{z}$ statistics tend to increase with the sample size. As the number of observations increases, the standard errors of the mean fall drastically, and even small differences between two observations are overstated. This is why the Sdiff is preferred.

This statistic is calculated as follows (see Rosenaum and Rubin 1985):

$$
\text { Sdiff }=\frac{\mu_{1}-\mu_{2}}{\sqrt[2]{\frac{\left(n_{2}-1\right) s_{1}^{2}+\left(n_{2}-1\right) s_{2}^{2}}{\left(n_{1}+n_{2}-2\right)}}}
$$

The statistic is indicating how many "standard" deviations exist between the mean of both groups. The rule of thumb is to consider more than 0.2 standard deviations as a considerably high difference between samples, but no formal statistic is provided. In Table A1, means from two samples are compared. The Matched Sample is the sample used in the analysis of this paper. The Unmatched Sample consist of the data for whom a previous year match was not found. The Sdiff values in bold are the only variables for which the Sdiff is larger than the conventional 0.2. 
Table A1. Sample means and their standardized differences, all ages $16+$.

\begin{tabular}{|c|c|c|c|c|c|c|c|c|}
\hline \multirow[t]{2}{*}{$\begin{array}{l} \\
\text { Characteristic }\end{array}$} & \multicolumn{2}{|c|}{$\begin{array}{c}\text { Matched } \\
\text { observations } \\
\text { (observed in } t-1 \\
\text { and observed in } t \text { ) } \\
\mathrm{N}=7.4 \mathrm{~m}\end{array}$} & \multicolumn{2}{|c|}{$\begin{array}{c}\text { Unmatched } \\
\text { observations } \\
\text { (observed in } t-1 \text { and } \\
\text { unobserved in } t \text { ) } \\
\mathrm{N}=3.1 \mathrm{~m}\end{array}$} & \multicolumn{2}{|c|}{$\begin{array}{c}\text { Full sample } \\
\text { (everyone } \\
\text { observed in } t-1 \text { ) } \\
\mathrm{N}=10.5 \mathrm{~m} \\
\end{array}$} & \multirow{2}{*}{$\begin{array}{c}\begin{array}{c}\text { Matched } \\
\text { vs. } \\
\text { Unmatched }\end{array} \\
\text { Sdiff } \\
\end{array}$} & \multirow{2}{*}{$\begin{array}{c}\text { Matched } \\
\text { vs. Full } \\
\text { Sample } \\
\text { Sdiff } \\
\end{array}$} \\
\hline & mean & SD & mean & SD & mean & SD & & \\
\hline Female & 0.528 & 0.499 & 0.513 & 0.500 & 0.523 & 0.499 & 0.030 & 0.009 \\
\hline Age & 46.858 & 17.73 & 40.612 & 18.001 & 44.987 & 18.04 & 0.349 & 0.105 \\
\hline Fam incom & 8.669 & 5.708 & 8.185 & 5.491 & 8.524 & 5.648 & 0.087 & 0.025 \\
\hline Ever married & 0.601 & 0.490 & 0.460 & 0.498 & 0.559 & 0.497 & 0.285 & 0.086 \\
\hline Less than Highschool & 0.174 & 0.379 & 0.194 & 0.396 & 0.180 & 0.384 & -0.052 & -0.016 \\
\hline High school & 0.318 & 0.466 & 0.316 & 0.465 & 0.317 & 0.465 & 0.003 & 0.001 \\
\hline Some College & 0.258 & 0.437 & 0.266 & 0.442 & 0.260 & 0.439 & -0.019 & -0.006 \\
\hline Ba degree & 0.165 & 0.371 & 0.154 & 0.361 & 0.161 & 0.368 & 0.031 & 0.009 \\
\hline Grad school & 0.086 & 0.280 & 0.070 & 0.255 & 0.081 & 0.273 & 0.061 & 0.017 \\
\hline White & 0.850 & 0.357 & 0.816 & 0.388 & 0.840 & 0.367 & 0.091 & 0.029 \\
\hline Black & 0.093 & 0.290 & 0.115 & 0.319 & 0.099 & 0.299 & -0.072 & -0.023 \\
\hline Other race & 0.050 & 0.219 & 0.062 & 0.240 & 0.054 & 0.226 & -0.047 & -0.015 \\
\hline Hispanic & 0.007 & 0.083 & 0.008 & 0.089 & 0.007 & 0.085 & -0.012 & -0.004 \\
\hline North East & 0.219 & 0.414 & 0.198 & 0.399 & 0.213 & 0.409 & 0.052 & 0.015 \\
\hline Mid West & 0.243 & 0.429 & 0.225 & 0.417 & 0.238 & 0.426 & 0.044 & 0.013 \\
\hline South & 0.302 & 0.459 & 0.317 & 0.465 & 0.306 & 0.461 & -0.032 & -0.010 \\
\hline West & 0.219 & 0.414 & 0.198 & 0.399 & 0.213 & 0.409 & 0.052 & 0.015 \\
\hline Employe & 0.628 & 0.483 & 0.630 & 0.483 & 0.629 & 0.483 & -0.004 & -0.001 \\
\hline Unemployed & 0.032 & 0.175 & 0.053 & 0.225 & 0.038 & 0.192 & -0.103 & -0.036 \\
\hline Retired & 0.180 & 0.384 & 0.120 & 0.325 & 0.162 & 0.369 & 0.175 & 0.048 \\
\hline Disabled & 0.048 & 0.214 & 0.054 & 0.225 & 0.050 & 0.218 & -0.024 & -0.007 \\
\hline School & 0.043 & 0.203 & 0.060 & 0.238 & 0.048 & 0.214 & -0.076 & -0.025 \\
\hline HHCare & 0.058 & 0.234 & 0.064 & 0.245 & 0.060 & 0.238 & -0.025 & -0.008 \\
\hline other & 0.011 & 0.103 & 0.018 & 0.134 & 0.013 & 0.113 & -0.060 & -0.021 \\
\hline \multicolumn{9}{|l|}{ Industry } \\
\hline & 0.031 & 0.175 & 0.029 & 0.168 & 0.031 & 0.173 & 0.014 & 0.004 \\
\hline Const & 0.070 & 0.256 & 0.078 & 0.268 & 0.073 & 0.259 & -0.028 & -0.009 \\
\hline Manufacturing & 0.127 & 0.333 & 0.116 & 0.320 & 0.124 & 0.329 & 0.035 & 0.010 \\
\hline Wholesale \& retail trd & 0.167 & 0.373 & 0.186 & 0.389 & 0.173 & 0.378 & -0.049 & -0.015 \\
\hline Trans. and utilities & 0.060 & 0.237 & 0.054 & 0.227 & 0.058 & 0.234 & 0.023 & 0.007 \\
\hline Information & 0.013 & 0.113 & 0.013 & 0.111 & 0.013 & 0.113 & 0.004 & 0.001 \\
\hline Financial activities & 0.068 & 0.251 & 0.062 & 0.242 & 0.066 & 0.248 & 0.021 & 0.006 \\
\hline Prof. and bus. services & 0.119 & 0.324 & 0.125 & 0.330 & 0.121 & 0.326 & -0.017 & -0.005 \\
\hline Ed. and health srves & 0.201 & 0.401 & 0.179 & 0.383 & 0.194 & 0.396 & 0.059 & 0.018 \\
\hline Leisure and hospitality & 0.052 & 0.222 & 0.075 & 0.264 & 0.059 & 0.236 & -0.091 & -0.031 \\
\hline Other servic & 0.041 & 0.199 & 0.042 & 0.202 & 0.042 & 0.200 & -0.006 & -0.002 \\
\hline Public administration & 0.050 & 0.217 & 0.041 & 0.198 & 0.047 & 0.212 & 0.042 & 0.012 \\
\hline \multicolumn{9}{|l|}{ Occupation } \\
\hline Man, bus., \& financial & 0.154 & 0.361 & 0.127 & 0.333 & 0.146 & 0.353 & 0.079 & 0.023 \\
\hline Professional \& related & 0.203 & 0.403 & 0.178 & 0.383 & 0.196 & 0.397 & 0.065 & 0.019 \\
\hline Service & 0.146 & 0.353 & 0.182 & 0.386 & 0.157 & 0.364 & -0.097 & -0.031 \\
\hline Sales and related & 0.113 & 0.317 & 0.120 & 0.325 & 0.115 & 0.320 & -0.021 & -0.006 \\
\hline Office \& admin support & 0.139 & 0.346 & 0.132 & 0.338 & 0.137 & 0.344 & 0.022 & 0.007 \\
\hline
\end{tabular}


Farm, fishing, \& forest Constr \& extraction Prod, install, maint Transp \& moving

\begin{tabular}{rr|rr|rr|rr}
0.018 & 0.133 & 0.018 & 0.134 & 0.018 & 0.133 & -0.001 & 0.000 \\
0.048 & 0.214 & 0.061 & 0.240 & 0.052 & 0.223 & -0.056 & -0.018 \\
0.127 & 0.333 & 0.127 & 0.333 & 0.127 & 0.333 & 0.000 & 0.000 \\
0.051 & 0.219 & 0.054 & 0.226 & 0.052 & 0.221 & -0.014 & -0.004 \\
\hline
\end{tabular}


Table A2. Sample means and their standardized differences, all ages 25-54.

\begin{tabular}{|c|c|c|c|c|c|c|c|c|}
\hline \multirow[t]{2}{*}{$\begin{array}{l}\text { Characteristic } \\
\text { Cha }\end{array}$} & \multicolumn{2}{|c|}{$\begin{array}{c}\text { Matched } \\
\text { observations } \\
\text { (observed in } t-1 \\
\text { and observed in } t \text { ) } \\
\mathrm{N}=4.1 \mathrm{~m}\end{array}$} & \multicolumn{2}{|c|}{$\begin{array}{c}\text { Unmatched } \\
\text { observations } \\
\text { (observed in } t-1 \text { and } \\
\text { unobserved in } t \text { ) } \\
\mathrm{N}=1.7 \mathrm{~m}\end{array}$} & \multicolumn{2}{|c|}{$\begin{array}{c}\text { Full sample } \\
\text { (everyone } \\
\text { observed in } t-1 \text { ) } \\
\mathrm{N}=5.8 \mathrm{~m}\end{array}$} & \multirow{2}{*}{$\begin{array}{c}\begin{array}{c}\text { Matched } \\
\text { vs. } \\
\text { Unmatched }\end{array} \\
\text { Sdiff }\end{array}$} & \multirow{2}{*}{$\begin{array}{c}\text { Matched } \\
\text { vs. Full } \\
\text { Sample } \\
\text { Sdiff }\end{array}$} \\
\hline & mean & SD & mean & SD & mean & SD & & \\
\hline Female & 0.522 & 0.500 & 0.503 & 0.500 & 0.516 & 0.500 & 0.038 & 0.012 \\
\hline Age & 40.541 & 8.245 & 37.835 & 8.567 & 39.727 & 8.435 & 0.319 & 0.098 \\
\hline Fam incom & 9.408 & 5.527 & 8.620 & 5.445 & 9.171 & 5.514 & 0.144 & 0.043 \\
\hline Ever married & 0.685 & 0.464 & 0.551 & 0.497 & 0.645 & 0.479 & 0.274 & 0.086 \\
\hline Less than Highschool & 0.099 & 0.298 & 0.127 & 0.333 & 0.107 & 0.309 & -0.087 & -0.028 \\
\hline High school & 0.314 & 0.464 & 0.319 & 0.466 & 0.316 & 0.465 & -0.011 & -0.003 \\
\hline Some College & 0.279 & 0.448 & 0.271 & 0.444 & 0.276 & 0.447 & 0.018 & 0.005 \\
\hline Ba degree & 0.209 & 0.407 & 0.194 & 0.396 & 0.205 & 0.403 & 0.037 & 0.011 \\
\hline Grad school & 0.099 & 0.299 & 0.089 & 0.284 & 0.096 & 0.295 & 0.037 & 0.011 \\
\hline White & 0.844 & 0.363 & 0.804 & 0.397 & 0.832 & 0.374 & 0.104 & 0.033 \\
\hline Black & 0.093 & 0.291 & 0.121 & 0.326 & 0.102 & 0.302 & -0.086 & -0.028 \\
\hline Other race & 0.055 & 0.229 & 0.068 & 0.251 & 0.059 & 0.236 & -0.050 & -0.016 \\
\hline Hispanic & 0.007 & 0.083 & 0.008 & 0.088 & 0.007 & 0.084 & -0.010 & -0.003 \\
\hline North East & 0.216 & 0.411 & 0.199 & 0.399 & 0.211 & 0.408 & 0.041 & 0.012 \\
\hline Mid West & 0.245 & 0.430 & 0.216 & 0.412 & 0.236 & 0.425 & 0.068 & 0.020 \\
\hline South & 0.297 & 0.457 & 0.321 & 0.467 & 0.304 & 0.460 & -0.050 & -0.015 \\
\hline West & 0.216 & 0.411 & 0.199 & 0.399 & 0.211 & 0.408 & 0.041 & 0.012 \\
\hline Employed & 0.811 & 0.391 & 0.768 & 0.422 & 0.798 & 0.401 & 0.104 & 0.032 \\
\hline Unemployed & 0.034 & 0.181 & 0.0 & 0.227 & 0.040 & 0.196 & -0.096 & -0.033 \\
\hline Retired & 0.011 & 0.104 & 0.0 & 0.093 & 0.010 & 0.101 & 0.024 & 0.007 \\
\hline Disabled & 0.046 & 0.209 & 0.054 & 0.225 & 0.048 & 0.214 & -0.036 & -0.011 \\
\hline School & 0.009 & 0.096 & 0.017 & 0.129 & 0.012 & 0.107 & -0.063 & -0.022 \\
\hline HHCare & 0.081 & 0.272 & 0.083 & 0.276 & 0.081 & 0.273 & -0.008 & -0.003 \\
\hline other & 0.009 & 0.093 & 0.015 & 0.123 & 0.011 & 0.103 & -0.059 & -0.021 \\
\hline \multicolumn{9}{|l|}{ Industry } \\
\hline Mining & 0.027 & 0.163 & 0.027 & 0.161 & 0.027 & 0.162 & 0.005 & 0.001 \\
\hline Construction & 0.075 & 0.264 & 0.084 & 0.277 & 0.078 & 0.268 & -0.031 & -0.010 \\
\hline Manufacturing & 0.138 & 0.345 & 0.129 & 0.335 & 0.136 & 0.342 & 0.029 & 0.008 \\
\hline Wholesale \& ret & 0.148 & 0.355 & 0.158 & 0.365 & 0.151 & 0.358 & -0.028 & -0.008 \\
\hline Trans. and utilities & 0.065 & 0.246 & 0.061 & 0.240 & 0.064 & 0.244 & 0.015 & 0.004 \\
\hline Information & 0.013 & 0.115 & 0.013 & 0.114 & 0.013 & 0.115 & 0.003 & 0.001 \\
\hline Financial activities & 0.070 & 0.256 & 0.067 & 0.249 & 0.069 & 0.254 & 0.015 & 0.004 \\
\hline Prof. and bus. services & 0.122 & 0.327 & 0.130 & 0.337 & 0.125 & 0.330 & -0.025 & -0.008 \\
\hline Ed. and health srves & 0.207 & 0.405 & 0.187 & 0.390 & 0.201 & 0.401 & 0.051 & 0.015 \\
\hline Leisure and hospitality & 0.041 & 0.198 & 0.057 & 0.232 & 0.046 & 0.209 & -0.072 & -0.023 \\
\hline Other servic & 0.039 & 0.192 & 0.040 & 0.197 & 0.039 & 0.194 & -0.009 & -0.003 \\
\hline Public admin & 0.054 & 0.226 & 0.047 & 0.212 & 0.052 & 0.222 & 0.032 & 0.009 \\
\hline \multicolumn{9}{|l|}{ Occupation } \\
\hline Man, bus., \& financial & 0.166 & 0.372 & 0.145 & 0.352 & 0.160 & 0.366 & 0.057 & 0.016 \\
\hline Professional \& related & 0.221 & 0.415 & 0.200 & 0.400 & 0.215 & 0.411 & 0.052 & 0.015 \\
\hline Service & 0.128 & 0.334 & 0.156 & 0.362 & 0.136 & 0.343 & -0.079 & -0.025 \\
\hline Sales and rela & 0.101 & 0.301 & 0.104 & 0.306 & 0.102 & 0.303 & -0.011 & -0.003 \\
\hline Office \& admin support & 0.137 & 0.344 & 0.128 & 0.334 & 0.134 & 0.341 & 0.026 & 0.007 \\
\hline
\end{tabular}


Farm, fishing, \& forest Constr \& extraction Prod, install, maint Transp \& moving

\begin{tabular}{rl|rr|rr|rr}
0.015 & 0.121 & 0.016 & 0.124 & 0.015 & 0.122 & -0.005 & -0.002 \\
0.047 & 0.213 & 0.060 & 0.237 & 0.051 & 0.220 & -0.053 & -0.017 \\
0.137 & 0.343 & 0.137 & 0.344 & 0.137 & 0.344 & -0.001 & 0.000 \\
0.049 & 0.216 & 0.055 & 0.228 & 0.051 & 0.220 & -0.025 & -0.008 \\
\hline
\end{tabular}

